\title{
PSA Level Four to Ten
}

National Cancer Institute

\section{Source}

National Cancer Institute. PSA Level Four to Ten. NCI Thesaurus. Code C153414.

A blood concentration of prostate specific antigen between $4 \mathrm{ng} / \mathrm{mL}$ and $10 \mathrm{ng} / \mathrm{mL}$. 